Private aviser og tv-kanaler er ettertraktede maktmidler, og brer hurtig om seg i Kuwait. I hvilken grad utfordrer de nye eierstrukturene det politiske systemet?

\title{
Mediemakt og politisk krise i Kuwait
}

Kjetil Selvik er forsker ved Fafo og førsteamanuensis II ved Institutt for kulturstudier og orientalske språk, Universitetet i Oslo. 
TEKST: Kjetil Selvik

UTVIKLINGEN I KUWAIT har de siste fem årene vært preget av to hovedtrekk. Landet har på den ene siden gjennomgått en rivende utvikling i medielandskapet, og på den annen side befunnet seg i en sammenhengende politisk krise. «Krise» er kuwaiternes eget ord for å beskrive ustabilitet og handlingslammelse i form av hyppige regjeringsskifter, mistillitsforslag og oppløsning av parlamentet. I begivenhetenes sentrum finner en statsminister Nasir alMuhammad, som siden 2006 har vært leder for seks ulike regjeringer og overlevd to mistillitsforslag og tre nyvalg. Han har så langt opprettholdt støtten fra sin onkel Sabah al-Ahmad, emiren av Kuwait, som utpeker regjeringen.

Utviklingen i medielandskapet startet i 2006 da Nasjonalforsamlingen vedtok å fjerne begrensninger på utstedelse av lisens for private dagsaviser, radio og tvstasjoner. Inntil da fantes intet alternativ til statlig radio og fjernsyn, samt fem private aviser som var blitt skjermet for konkurranse siden 1976 fordi Innenriksministeriet blokkerte alle søknader om nye konsesjoner. Men ikke før var de nye lovene for presse, publisering, radio og tv på plass før medietilbudet eksploderte. Ti nye arabiskspråklige aviser ble opprettet i løpet av tre år og antall private tv-stasjoner økte fra fem til atten. Dertil kommer en enda større økning i internettbaserte mediekanaler som nettaviser, blogger og diskusjonsfora, som ikke er tema for denne artikkelen. ${ }^{\mathrm{T}}$

Liberalisering av medielovene hadde vært et stående krav fra sivilsamfunnet og ble i 2006 sett i sammenheng med flere positive utviklingstrekk i tiden. Først fikk kvinner stemmerett i 2005 og deretter mobiliserte en bred folkelig bevegelse for reorganisering av valgsystemet, noe myndighetene måtte etterkomme. I 2006 ble også den folkevalgte nasjonalforsamlingen avgjørende for valget av emir innad i den herskende Sabah-familien. Det lå en fornemmelse av demokrati i luften.

Men fem år med økende mediemangfold har ikke gjort stort for å bringe demokratiet videre, snarere tvert imot: Det kuwaitiske semidemokratiet virker i dag mer fastlåst i sine egne begrensninger enn på lenge. Krisen kulminerte i desember 20Iо da regimets sikkerhetsstyrker angrep en samling i regi av opposisjonen og på høyst uvanlig vis slo løs på sittende parlamentsmedlemmer med køller. ${ }^{2}$ I oppstyret som fulgte stengte regjeringen satellittkanalen Al Jazeera og advarte om at den ville søke å innføre nye restriksjoner i landets medielover. Opposisjonen svarte med sinne og mistillitsforslag mot statsminister 
Nasir al-Muhammad i parlamentet, og anklaget regjeringen for mangelfull og partisk håndhevelse av medielovene.

Opposisjonens misnøye med media er minst like stor som regjeringens. I de opphetede parlamentsdebattene etter sammenstøtene i desember 20Io satt skjellsordene løst mot det opposisjonspolitikeren Faisal al-Muslim har døpt «de korrupte media» (al-ilam al-fasid). ${ }^{3}$

At regjeringen truer med å slå ned på media i en stat hvor Sabah-familien har monopol på utøvende myndighet er ikke vanskelig å skjønne, men nysgjerrigheten øker når også opposisjonen langer ut mot nyoppstartede aviser og tv-kanaler den selv har vært med å legge til rette for. Ettersom liberalisering av mediesektoren reduserer statens direkte kontroll og åpner tilgangen for nye aktører skulle en kanskje forvente en sterkere dominans av opposisjonsstøttede og regjeringskritiske media.

Litteraturen om mediesystemer som liberaliseres i gryende demokratier eller liberaliserte autokratier finner imidlertid ofte en langt mer kompleks og kaotisk virkelighet hvor nye og gamle eliter kjemper om innflytelse. ${ }^{4}$ Privatisering av domener som tidligere var underlagt direkte statlig styring trenger ikke bety tap av politisk kontroll hvis aktørene som overtar slike funksjoner tilhører samme elitenettverk og har grunnleggende like interesser. ${ }^{5}$ I tilfellet arabisk media har for eksempel Naomi Sakr vist hvordan satellittfjernsyn som vokste frem i I990-årene ble nye maktmidler for regimer og regimenære forretningsmoguler ${ }^{6}$ som brukte sin kontroll over blant annet infrastruktur, informasjon og pengestrømmer til å marginalisere regimekritiske kanaler.?

I tråd med denne innsikten retter denne artikkelen søkelyset mot eierskapsstrukturene i de nye kuwaitiske mediene og spør i hvilken grad de utfordrer det politiske systemet. Ved å klargjøre hvilke politiske og økonomiske interesser som ligger bak den nye mediescenen ønsker jeg å gi innsikt i hvor vidt medieliberalisering har endret maktbalansen mellom stat og samfunn i Kuwait, som igjen er en viktig forutsetning for demokrati.

\section{Stat og samfunn i Kuwait}

La oss begynne med å klargjøre hva som kjennetegner forholdet mellom stat og samfunn i Kuwait. I sin enkleste forstand er politikken en kamp mellom herskerfamilien, Al Sabah, og folket om kontroll over landets utvikling. Folket stiller med sterkere kort enn i de fleste andre arabiske stater fordi Kuwait har en grunnlov av I962 som gir gode sivile rettigheter, samt et folkevalgt parlament med sterk lovgivende myndighet og autoritet til å holde regjeringen i tømmene. Trumfkortet i så måte er retten til å «grille», som sjargongen sier, medlemmer av regjeringen og ved flertall stemme dem ned. Emiren har på sin side mulighet til å oppløse parlamentet og utlyse nyvalg innen to måneder dersom han synes parlamentet blir for ustyrlig. Ved to historiske anledninger, henholdsvis i periodene 1976-I981 og 1986-I992, har også emiren vendt grunnloven ryggen, oppløst parlamentet i årevis, og styrt gjennom dekreter. Da mobiliserte imidlertid sivilsamfunnet for politiske rettigheter, for forventningen om representasjon gjennom valg sitter dypt i kuwaiternes politiske kultur.

Samfunnets evne til politisk organisering styrkes av spesifikt kuwaitiske institusjoner som diwaniyya, åpne sosiale sam- 
linger i private hjem, som regimet har vanskelig for å kontrollere. ${ }^{8}$ I disse møteplassene for kuwaitiske menn går praten raskt, løst og fritt om alt fra fotball til politikk. Diwaniyya-institusjonen har særlig vist seg viktig i perioder hvor offisielle politiske plattformer har vært stengt. ${ }^{9}$ En annen styrke ved sivilsamfunnet er ikke-statlige organisasjoner (NGOer), som i større grad enn de fleste andre arabiske land har fått operere uten statlig innblanding.

Der regimet setter grenser for politisk organisering er imidlertid i forhold til partier som formelt sett ikke har lov til å eksistere, og som i praksis må leve med en rekke begrensninger. Politiske organisasjoner som den liberale Den demokratiske plattform, ${ }^{\text {10 }}$ Muslimbrødrenes politiske arm Hadas $^{\text {II }}$ og shia-islamistenes Nasjonal islamsk allianse ${ }^{\mathrm{i} 2} \mathrm{er}$, tross forbud mot å kalle seg det, for alle praktiske formål politiske partier. De kan for eksempel organisere konferanser, holde demonstrasjoner og lage valglister. Samtidig gjør mangelen på partilov med klart definerte rettigheter at de må operere innen visse uuttalte grenser for hva regimet vil akseptere. Første bud er å rekruttere og mobilisere innebfor sine respektive samfunnssjikt ${ }^{\text {13 }}$ og ikke gjøre forsøk på politisk organisering som spenner over samfunnet som helhet. Forsøk på å samle et flertall av parlamentsmedlemmene i et sentralstyrt og permanent politisk parti er også langt mer enn regimet vil akseptere. Selv de politiske organisasjonene som finnes i dag kan ikke opprette en bankkonto eller telefonlinje, leie lokaler eller gå til sak i rettsvesenet i partiets navn.

Formålet med den begrensede institusjonaliseringen er på den ene siden å holde potensiell opposisjon i en prekær situasjon hvor partiene er avhengige av godvilje fra regimet. På den annen side avhenger Sabah-familiens dominerende posisjon av at samfunnet er splittet av personlige, ideologiske og sekteriske motsetningsforhold. Fraværet av permanent politisk organisering på tvers av samfunnets skillelinjer har gjort politikk til en kamp mellom segmenterte «interessegrupper» som ofte har et snevert sekterisk fokus. Et klart skille går mellom det kuwaitiske samfunnets tre hovedgrupper: historisk sedenteriserte sunnimuslimer (hadar), sunnimuslimer med stammetilknytning (badu) og shiamuslimer. Disse er igjen segmentert i undergrupper langs ideologiske og personlige akser. ${ }^{14}$ For beduinenes del er stammevesenet den sterkeste segmenterende kraft, og for shiamuslimene spiller også etnisitet en viss rolle. ${ }^{15}$

Siden olje dominerer økonomien og staten holder nøkkelen til fordeling av oljeinntektene, inngår de ulike samfunnsgruppene i en økonomisk interessekonflikt om hvem som skal få den største delen av kaken. Politiske representanter i parlamentet, regjeringen og andre sentrale institusjoner vurderes av sine tilhengere i stor grad på grunnlag av hvor effektive de er i å sikre velferd for sine respektive grupper. Segmentert klientellisme svekker sivilsamfunnets evne til kollektivt politisk press og mobilisering. ${ }^{16}$ Den legger også til rette for politisering av sekteriske identiteter som vi skal komme inn på senere.

I tillegg til konfliktlinjer i samfunnet, preges også kuwaitisk politikk av spenninger og maktkamp mellom medlemmer av herskerfamilien. ${ }^{\text {17 }}$ Etterfølgerne etter Mubarak al-Sabah (I896-I9I5), som grunnla regimet, er delt i fire familiegrener 
med ulik innflytelse: al-Jabir, al-Salim, alHamad (eller al-Mubarak al-Hamad) og alNasir. Inntil nylig vekslet arveretten til landets emirer mellom Jabir- og Salimgrenene av familien, men etter at emir Jabir al-Ahmad ble avløst av emir Sabah og kronprins Nawwaf i 2006 - som begge tilhører den samme Jabir-klanen - kan det virke som om Salim-grenen har tapt spillet for godt i den interne kampen om tronen.

Uavhengig av familiegren raser rivaliseringen permanent om å posisjonere seg som kronprins ved neste maktskifte. Kandidater til stillingen som kronprins i Kuwait utpekes av emiren, men må godkjennes av parlamentet. Dersom sistnevnte vender tommelen ned er emiren forpliktet av grunnloven til å foreslå tre kandidater og la parlamentet velge. Det betyr at parlamentet har uvanlig mye innflytelse i utnevnelsen av kronprins, noe som igjen gjør at kronprinsemner må pleie sine kontakter og bygge allianser blant de folkevalgte. Livet i nasjonalforsamlingen har fra starten av dets eksistens på I96o-tallet vært preget av påvirkning fra rivaliserende medlemmer av Sabah-familien, som enten skjult eller åpent har etablert sine blokker av støttespillere. Fordi prinsene som regel har store finansielle ressurser til rådighet inkluderer denne praksisen ofte «kjøp» av politisk støtte.

I dagens situasjon er det særlig medlemmer av Jabir-familien som prøver å posisjonere seg i forhold til å bli kronprins den dagen emir Sabah går i graven. Den første er statsminister Nasir al-Muhammad, som er emirens nevø og den eldste av de aktuelle kandidatene. ${ }^{18}$ Nummer to i alder er Jabir al-Mubarak, som vil være en het kandidat til å overta jobben som statsminister dersom Nasir al-Muhammad blir felt av krisen. Han er imidlertid ikke regnet som den mest dedikerte og sterkeste «fighteren». Her fremtrer en tredje og langt yngre kandidat, mest kjent for sitt voldsomme engasjement, politisk teft og personlig karisma: Ahmad al-Fahd, som er nå visestatsminister, ble lenge holdt utenfor regjeringen av sin rival Nasir alMuhammad, men brukte sin innflytelse i parlamentet til å skape så mye uro at statsministeren ikke så noen annen rå enn å inkludere ham i kabinettet.

Spenningene internt $i$ familien forplanter seg til og forsterker spenningene $i$ samfunnet. De konkurrerende kronprinsemnene allierer seg nemlig med rivaliserende deler av samfunnet i sin kamp for å sikre seg flertall i parlamentet. Grovt skissert er alliansemønsteret i dag som følger: Nasir al-Muhammad har støtte blant shiaene, en del liberale sunni hadar og den ene av to salafi-grupper i parlamentet; ${ }^{19}$ Jabir al-Mubarak har støtte blant den stammedominerte opposisjonsgruppen alTakattul al-Sha'bi og den liberale sunni hadar-gruppen al-'Amal al-Watani; Ahmad al-Fahd har stor oppslutning blant stammene og den andre salafi-gruppen i parlamentet. $^{2 \circ}$ Når representantene for disse samfunnsgruppene braker sammen i parlamentet er det aldri godt å vite i hvilken grad de rivaliserende medlemmene av Sabah-familien har en finger med i spillet.

\section{Nye medieaktører}

Nå som vi har et klarere bilde av hva som kjennetegner Kuwaits politiske kontekst og forholdet mellom stat og samfunn kan vi gå tilbake til temaet for denne artikkelen, som er effekten av liberalisering av mediesektoren. Spørsmålet om media, sivilsamfunn og demokrati angripes ofte 
fra vinkelen pressefrihet og mulighet for kritikk av regimet, men Kuwait har lenge hatt stor politisk takhøyde, ${ }^{21}$ og denne analysen er mer interessert i det som ligger bak nyhetsbildet i form av eierskap i mediesektoren. I stedet for å gå rett på en vurdering av størrelser som sivilsamfunn og demokrati vil jeg starte med å besvare tre mindre og håndfaste spørsmål: Hvem har inntatt media siden 2006? Hvorfor har de inntatt media? Og hvordan brukes media politisk?

Inntil 2006 besto medietilbudet i Kuwait som nevnt i introduksjonen av fem private arabisk-språklige dagsaviser og statlige radio- og tv-kanaler. Det nasjonale

\section{mom \\ Aktørene oppfatter aviser og tv- kanaler som svoert viktig for å påvirke utfallet av politiske prosesser.}

radio og tv var som de fleste statskontrollerte media i regionen tannløst og konformt, men avisene ga rom for kritikk og et bredt spekter av meninger fra ulike samfunnssegmenter. Samtidig var førstesider, ledere og vinklinger i spesielle saker preget av eiernes interesser og politiske orientering.

Kort fortalt var bildet som følger: Kuwaits største og viktigste avis al-Watan er eid av 'Ali al-Khalifa, et medlem av alSabah-familien (utenfor arvingene etter Mubarak som kan vinne tronen) og en fremtredende forretningsmann; den velrenommerte avisen al-Qabas er eid av fem store sunni hadar-handelsfamilier som historisk har vært ledende i Kuwaits Handelskammer; Kuwaits tredje viktigste avis al-
Ra'i tilhører en annen forretningsmann i tungvektsklassen, Jasim al-Buda'i, som også er sunni hadar, men ikke av tradisjonell «aristokratisk» ætt som eierne av alQabas; al-Siyasa eies av den sterkt pro Al Sabah Ahmad al-Jarallah, en forretningsmann som også støtter massivt opp om andre konservative, pro-vestlige arabiske regimer; al-Anba' tilhører forretningsmannen Khalid al-Marzuq og er i likhet med alSiyasa så konform at den kunne vært en statlig avis. ${ }^{22}$

Til disse fem avisene, som alle ble stiftet før I976, sluttet det seg i perioden 2007 til 2010 ti nye arabiskspråklige dagsaviser som utvidet sirkelen av medieeiere betraktelig. De nye avisene brakte også nye politiske orienteringer til torgs som ikke tidligere hadde hatt sine egne mediekanaler. Det gjelder særlig al-Dar, som under ledelse av forretningsmannen Mahmud Haydar har en eksplisitt shia-muslimsk orientering. Avisen er for eksempel den eneste som bryter «tabuet» i kuwaitisk sammenheng med å åpent kritisere innflytelsen til nabolandet Saudi-Arabia og som på layoutnivå går i svart og vier hele førstesider til ikonlignende bilder av Imam Hussein under shiamuslimenes sørgemåned muharram; Arrouiah [al-Ru'ya] var eid av salafi-alliansen til forretningsmannen og parlamentsmedlemmet Khalid alSultan og representerte første offisielle organ for kuwaitiske salafi-muslimer; ${ }^{23}$ 'Alam al-Yawm støtter den viktigste opposisjonsblokken i parlamentet, al-Takattul alsha'bi og forsvarer «vanlige stammefolks» perspektiv som ellers er underrepresentert i media. ${ }^{24}$

En annen trend som allerede burde være tydelig fra de foregående avsnitt er at forretningsmenn dominerer blant kuwaitiske 
aviseiere. Ytterligere tre av de nye dagsavisene eies av forretningsmenn direkte. Den første er al-Nahar til Jawad Bukhamsin, som er en suksessrik shia-investor med opphav i al-Ahsa' i Saudi-Arabia. Avisen har en langt mer nedtonet og konform shia-profil enn den ovennevnte alDar. Den andre er al-Wasat, tilhørende 'Adnan Muhammad al-Wazzan hvis familie stammer fra Najd i Saudi-Arabia. Al-Wasat samarbeidet en periode med Muslimbrødrene i Kuwait, som satte sitt preg på avisens orientering, men samarbeidet brøt sammen og al-Wasat er per i dag en lite lest avis med liten distribusjon. Den tredje er al-Jarida som eies av Muhammad al-Saqr, en annen forretningsmann av stort kaliber. Al-Saqr er en av de fem tradisjonelle handelsfamiliene som eier den gamle avisen al-Qabas hvor Muhammad al-Saqr har lang erfaring som redaktør. ${ }^{25}$

De resterende publikasjonene kan på direkte eller indirekte vis knyttes til medlemmer av herskerfamilien Al Sabah. Al-Shahid tilhører Sabah Muhammad, en ambisiøs, men i utgangspunktet perifer prins i herskerfamilien. Han har vunnet en stemme i offentligheten som kan være provoserende og tabloid $\mathrm{i}$ formen, og går ikke av veien for åpen konflikt med andre deler av Sabah-familien som 'Ali al-Khalifa i al-Watan. ${ }^{26}$ I tilfellet tre andre aviser, alSabah, al-Huriya, og Awan, er eierne offisielt akademikere og journalister. ${ }^{27}$ Den allmenne oppfatningen blant journalister og politiske observatører er imidlertid at statsminister Nasir al-Muhammad i det skjulte finansierer disse avisene. Alle tre har trofast støttet og forsvart statsministeren fra slag til slag i den politiske krisen. Awan var, før den gikk konkurs og ble stengt i mai 2oIo, den mest nyanserte, men de gjenværende al-Sabah og al-Huriya kan med rette beskrives som talerør for Nasir al-Muhammad..$^{28}$

Liksom antall arabiskspråklige aviser ble tredoblet etter 2006 har også utviklingen i det kuwaitiske tv-markedet skutt i taket. Fra Kanal I åpnet i I96I, via den engelskspråklige Kanal 2 i i987, hadde kuwaitisk tv per 2006 lansert fem statlige kanaler. ${ }^{29}$ Ved inngangen av 20II var dette tilbudet også nesten firedoblet. ${ }^{3 \circ}$ De toneangivende kanalene er al-Watan, al-Rai, al-Scope, al-Sabah, al-Adala og al-Funun. Al-Watan drives av 'Ali al-Khalifa, som også eier landets største avis, og er den mest påkostede og profesjonelle av de private tv-kanalene, og legger særlig vekt på lokale nyheter. Al-Rai var den første private tv-kanalen og tilhører forretningsmannen Jasim al-Buda'i i likhet med avisen med samme navn. Den formidler både kuwaitiske og internasjonale nyheter og er en god nummer to i presentasjon og popularitet.

Et godt stykke etter følger neste divisjon av private tv-kanaler, som har mindre midler til rådighet. Al-Scope drives av en kvinne ved navn Fajr al-Sa'id som oppfattes å være alliert med statsminister Nasir alMuhammad fordi hun kritiserer, og tidvis gjør narr av, fremtredende representanter for den stammeorienterte og islamistiske opposisjonen. Kanalen fokuserer på lokalpolitikk og diskusjonsprogrammer og har blant annet innført åpne linjer hvor seerne kan ringe inn og uttrykke sine meninger direkte om temaene som diskuteres. Al-Sabah er søster av avisen med samme navn, og oppfattes i likhet med al-Scope som finansiert og kontrollert av Nasir al-Muhammad. Tilbudet fra alSabah består i hovedsak av lokale nyheter og diskusjonsprogrammer. 


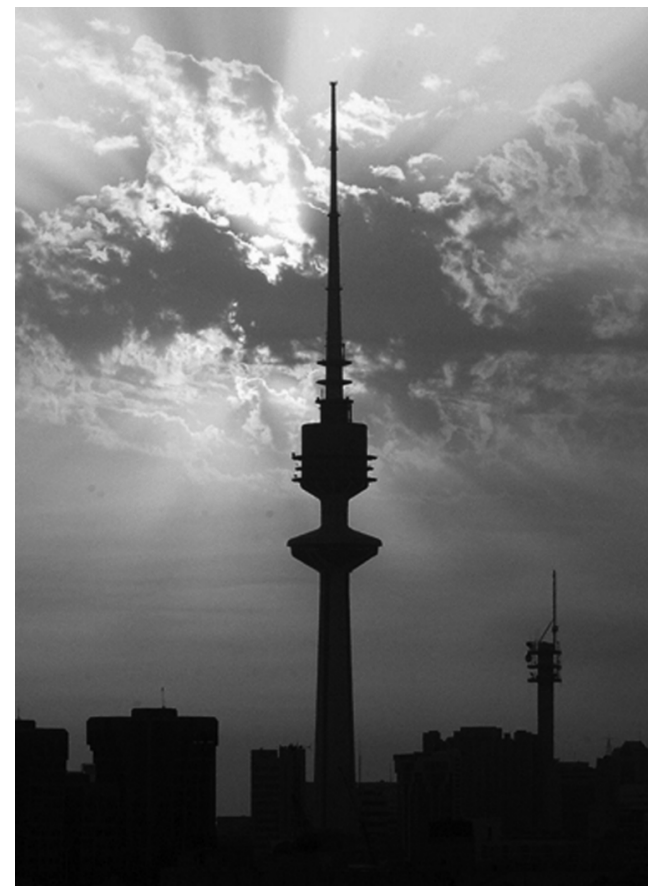

Fjernsynstårn i Kuwait.

Resten av de nye private tv-kanalene med betydning tilhører en forretningsmann som gjennom sine målrettede investeringer i mediekanaler har fått tilnavnet «Kuwaits Robert Murdoch». Det dreier seg om den ovennevnte finansmannen bak avisen al-Dar, Mahmud Haydar, som ifølge observatører i bransjen skal være eier av I5-I6 private tv-kanaler. ${ }^{3 \mathrm{I}}$ De to mest kjente i Kuwait er al-Adala og alFunun, hvor den første fokuserer på sport og lokalpolitikk og den andre er en ren underholdningskanal. Mahmud Haydar regnes i dag som en av landets rikeste menn. Inntil slutten av I990-årene var han imidlertid en relativt ukjent forretningsmann av middelklassebakgrunn. Haydars status som «nyrik» og hans klart betonte shia-muslimske profil har gjort ham til en kontroversiell skikkelse i Kuwait, og særlig i den stammeorienterte og sunniislamistiske opposisjonen. Hans fiender beskylder ham for å stå i ledtog med Iran og tror han driver sin business med og for statsminister Nasir al-Muhammad.

\section{Medias makt}

$\AA$ starte opp en dagsavis eller tv-kanal i Kuwait er en svært kostbar affære. Kilder i journalistmiljøet anslår årlig investering for å få en avis på beina til tre millioner kuwaitiske dinarer, KD, (63 millioner NOK) i tre til fem år før inntektene, hvis en lykkes, kan begynne å dekke de løpende utgiftene. ${ }^{32}$ Prisen for å få en privat tvstasjon på luften vurderes av direktør i statlig tv, Ali al-Rayyes, til mellom I og I,5 millioner dollar i året. ${ }^{33}$ Fordi antallet aviser og tv-stasjoner har økt så kraftig parallelt med at krisen i det internasjonale finansmarkedet rammet reklamemarkedet, er det langt vanskeligere enn tidligere å reklamefinansiere mediekanalene. Utgiftene kan heller ikke dekkes av salgspris ettersom kundene er vant til å få sine tv-programmer gratis og avisene til roo fils, eller rundt fire kroner. Overraskende nok har mediemarkedet tross dette opplevd svært få konkurser, ${ }^{34}$ og eierne fortsetter å pøse inn midler til papirleverandører, trykkerier og ansatte.

Rasjonaliteten bak investeringene i media er ikke i første rekke økonomisk; en mer overbevisende forklaring på hvorfor så mange aktører har inntatt mediebransjen er å finne i den politiske konteksten. Kvalitative intervjuer med redaktører, journalister og politiske kommentatorer indikerer at aktørene oppfatter aviser og tv-kanaler som svært viktig for å sette agenda og påvirke utfallet av politiske prosesser. ${ }^{35}$ Dette skyldes ulike forhold, men utgangspunktet er parlamentets makt og politikernes behov for å følge, om ikke lede, opinionen. Ikke 
bare det å bli valgt, men like mye evnen til å påvirke regjeringen, krever at parlamentarikerne er i takt med folkemeningen. Dette øker avkastningen på å forme opinionen. Den største makten ligger ikke nødvendigvis hos politikerne, men hos dem som produserer den dominerende diskurs og kan tvinge politikerne til å handle på visse måter.

Den ustabile politiske konteksten siden 2006 styrker dette poenget. Statsminister Nasir al-Muhammad kom tidlig under press fra sine motstandere i samfunnet og rivaler innad i herskerfamilien. Særlig

\section{Offentligheten kontrolleres av en gruppe svoert rike menn som i siste instans har felles klasseinteresser.}

Ahmad al-Fahd og hans allierte $\mathrm{i}$ den sunni-islamistiske og stammedominerte opposisjonen investerte i å skape vanskeligheter for regjeringen og kriser i parlamentet. Det inkluderte angrep på regjeringens politikk i aviser som al-Watan, al-Ra'i og 'Alam al-Yawm, og til dels også krasse spalter i al-Qabas og al-Jarida. Landets ledende avis og tv-kanal al-Watan, og i noe mindre grad også al-Qabas og al-Ra'i, har en påvirkningskraft på opinionen som tilsier at de langt på vei kan definere innholdet i en «krise» eller sak. Nasir al-Muhammad var derfor nødt til slå tilbake og har gjort det ved å opprette egne mediekanaler som Sabah, al-Huriya, Awan og Scope. I tillegg allierte han seg tett med Mahmud Haydar.

En annen faktor som øker medias betydning er det sterke personfokuset i kuwaitisk politikk. I fravær av godt institusjonalis- erte partier, med en overvekt av uavhengige politikere i parlamentet, og med velgere som synes å favorisere personlig tillit fremfor politiske programmer og ideologier, er evnen til personangrep ett av medias giftigste våpen. At media brukes til å angripe politiske motstandere er ikke unikt for Kuwait, men den hyppige forekomsten av «grillinger» i parlamentet, samt regjeringskoalisjonens ustabile fundament, øker markedsverdien av det medielitteraturen kaller «angrepshunder». ${ }^{36}$ Et klassisk eksempel som fikk store politiske konsekvenser var svertekampanjen i al-Watan mot de shiamuslimske parlamentarikerne 'Adnan 'Abd al-Samad og Ahmad Lari da de to holdt sørgestund for den drepte Hizballah-lederen 'Imad Mughniye i 2008. AlWatan fokuserte på Mughniyes bakgrunn som flykaprer i Kuwait og kjørte så hardt mot parlamentarikerne at de ble ekskludert fra sin politiske gruppe al-Takattul alsha'bi. ${ }^{37}$

Sist, men ikke minst, kommer medias makt til syne når det er valg i Kuwait, og det skjer takket være den politiske krisen ofte. Valgkampmånedene er høysesong for reklamemarkedet, ${ }^{38}$ og ingen lover regulerer hvor mye en kan investere i kandidatenes bilder og valgløfter. Kandidatenes mediebudsjett er ofte mellom I0० ००० og $200000 \mathrm{KD}$ (2,I-4,2 millioner kroner) og kan overskride I million KD (2I millioner kroner) for de mektigste, som parlamentspresident og forretningsmann Jasim al-Khorafi. ${ }^{39}$

Media er sin markedsverdi bevisst og krever ifølge valgkampledere ofte reklamemidler fra kandidatene for i det hele tatt å dekke deres uttalelser, program og aktiviteter. Den som ikke har penger kan med andre ord ikke regne med å havne i 
media, og uten mediedekning er sjansen for å bli valgt minimal. Medieeiere tilbyr av og til lovende kandidater gratis eller subsidiert annonseplass, men hempen er da at politikerne blir stående i gjeld til sine «velgjørere» og kan måtte gjøre gjenytelser eller forplikte seg til å stemme på visse måter når de inntar parlamentet. ${ }^{\circ}$

\section{Politiske konsekvenser}

Hvordan skal vi da forstå utviklingen i kuwaitiske media siden 2006? Det vi nettopp har konstatert med hensyn til medias eierskapsstruktur og makt gir lite støtte til den intuitivt appellerende idé at den har styrket sivilsamfunnet. Hovedproblemet er de enorme utgiftene som er forbundet med å opprette og drive en avis eller tv-kanal i emiratet. Det er nemlig de færreste som har de nødvendige finansielle ressurser, og de fleste medieeiere er som vi har sett i det foregående enten forretningsmenn eller medlemmer av herskerfamilien. Sistnevnte kan på ingen måte regnes som en del av sivilsamfunnet, men også de førstnevnte er som regel tett bundet til staten på grunn av oljens altoverskyggende betydning for den kuwaitiske økonomien. Offentligheten kontrolleres med andre ord av en gruppe svært rike menn som i siste instans har felles klasseinteresser.

Journalister og politiske observatører konstaterer at eiernes politiske og økonomiske interesser får negative konsekvenser for medias uavhengighet. ${ }^{4 \mathrm{I}}$ Medieeiere i Kuwait er som regel ikke klart adskilt fra redaktørene og blander seg i redaksjonelle prosesser. Skribenter opplever at artiklene deres blir avvist eller endret hvis de strider mot avisens politiske orientering. Kritikk av selskaper som annonserer eller på andre måter er viktige for eierens økonomiske interesser kan også være nok til å sensurere tv-innslag eller artikler.

En interessant politisk dynamikk har likevel oppstått fordi kuwaitiske medieeiere har gått i strupen på hverandre og kjemper om innflytelse gjennom sine aviser og tvkanaler. Spørsmålet er imidlertid om det er rimelig å forvente at den pluraliserende effekten dette innebærer skal bidra til demokratisering. Så langt er det mer som tyder på at det er en sammenheng mellom den nye medievirkeligheten og intensiteten i den politiske krisen. Flere av de nye mediene, og særlig enkelte tv-kanaler, har bidratt til å sette sinnene i kok. Årsaken ligger i økende tabloidisering av form og innhold ettersom konkurransen har økt og inflasjonen i journalistjobber har senket standarden for hvem som kan utøve yrket. Tonen preges i voksende grad av personangrep og sjikane. Ved flere anledninger har krasse ordskifter eskalert til fysiske angrep på journalister og medieinstitusjoner, som da rasende folkemengder raserte tvkanalen Scope i oktober 20I0, ${ }^{42}$ eller da de slo eieren av tv-kanalen al-Sur, Muhammad al-Juwaihil, bevisstløs i desember 20 го.

De harde medieslagene ser særlig ut til å ha en forsterkende effekt på segmenteringen i det kuwaitiske samfunnet. Som tidligere nevnt har en av hovedaktørene, statsminister Nasir al-Muhammad, en sekterisk distinkt politisk base (overveldende shia og hadar), og hans mediekanaler har ikke gått av veien for å levere sterke angrep på sunni-islamister og representanter fra stammene. I fravær av politiske institusjoner som spenner på tvers av slike samfunnsskiller har politiseringen bidratt til å gjøre splittelsen dypere. Dermed svekkes også samfunnets evne til kollektiv han- 
dling. Dess mer identitetsspørsmål får styre de politiske konfliktlinjene dess lettere blir det for Sabah-familien å videreføre sin privilegerte stilling.

\section{Konklusjon}

Hvilken utfordring representerer dermed den nye mediestrukturen i Kuwait for det politiske systemet? Regjeringen har et anstrengt forhold til private aviser og tvstasjoner fordi de er relativt frie og retter fokus mot styringsproblemer og maktmisbruk i utøvende myndighet. Ikke desto mindre anklager samtidig opposisjonen statsminister Nasir al-Muhammad for å korrumpere media og angripe den via stedfortredere. En skulle kanskje tro at liberalisering av mediesektoren ville bidra til å svekke makthaverne ettersom statlig kontroll over media har vært en nøkkel til arabiske regimers overlevelse. Liberalisering har imidlertid ikke et nødvendig motstykke i demokratisering, og for Kuwaits vedkommende har effekten så langt snarere vært krisemaksimering. Et hovedproblem er den høye finansielle inngangsbilletten for å etablere seg i mediesektoren. Det er stort sett bare forretningsmenn og medlemmer av Sabah-familien som har hatt råd til å opprette aviser og tv-kanaler. I en oljeøkonomi som Kuwait betyr det at styrkeforholdet mellom stat og samfunn ikke endres. Mediekanaler er, som denne artikkelen har vist, sentrale maktmidler, men kun for de som også hadde makt i utgangspunktet.

Den som håpet at private aviser og tvkanaler skulle rokke ved fundamentet for Sabah-familiens maktmonopol vil med andre ord bli skuffet, men andre former for media kan fortsatt utfordre makteliten. Utviklingen i nettbaserte mediekanaler har ikke vært mindre spektakulær enn omveltningene i de konvensjonelle media, og vil trolig ha forskjellig politisk effekt. Hovedforskjellen ligger $i$ at terskelen for å etablere nettaviser, blogger og diskusjonsfora er så mye lavere og derfor åpner for å gi folket makt.

$$
\cdot f \cdot
$$

I Flere enn tyve private nyhetssider har blitt opprettet i løpet av de siste årene hvor alle politiske retninger i Kuwait er representerte. Den kuwaitiske bloggosfæren har dessuten utviklet seg i rekordfart (se http://www.kuwaitblogs.com/; og "Mapping the Arabic Blogosphere: Politics, Culture and Dissent | Berkman Center," n.d., http://cyber.law.har vard.edu/publications/2009/Mapping_the_Arabic_Blo gosphere.)

2 “al-Rai o9.I2.Io," n.d., http://www.alraimedia.com/alrai /pdfs.aspx?date=09I220I0. (05.02.II)

3 Forfatters observasjoner i Kuwaits nasjonalforsamling I4.-I5. desember 2010.

4 Se for eksempel Blankson, Isaac A. og Patrick D. Murphy: Negotiating Democracy: Media Transformations in Emerging Democracies. Albany: State University of New York Press, 2007; Gross, Peter: Entangled Revolutions: Media and Democratiation in Eastern Europe. Baltimore, Maryland: Johns Hopkins University Press, 2002; Hyden, Goran, Michael Leslie og Folu F. Ogundimo: Media and Democracy in Africa. New Brunswick, New Jersey: Transaction Publishers, 2003.

5 Hibou, Beatrice (red): Privatising the State. London: Hurst $\&$ Co, 2004 .

6 Sakr, Naomi: Satellite Realms: Transnational Television, Globalization Q the Middle East. London og New York: I.B. Tauris, 200I.

7 Sakr, Naomi: Arab Television Today. London og New York: I.B. Tauris, 2007.

8 Al-Hajeri, Abdullah Mohammad: "The Development of Political Interaction in Kuwait Through the 'Diwaniyyas' from their beginnings until the year 1999" [upublisert manuskript, fått av forfatter]

9 al-Najjar, Ghanim: Nushat wa tatawwur al-dimuqratiya fi-l kuwait. Kuwait Universitet [Undervisningskompendium], 2010 .

Io al-minbar al-dimuqrati.

II Akronym for al-haraka al-dusturiya al-islamiya, Den islamske konstitusjonelle bevegelsen.

I2 al-'itilaf al-watani al-islami.

I3 For de ovennevnte partiene vil det si henholdsvis liberale sunni hadar, sunni-islamister, og shia-islamister. 
I4 Det viktigste ideologiske skillet er mellom liberale og islamister, men islamisme vidt definert er igjen sammensatt av muslimbrødre, salafier og shia-islamister. Betydningen av personlige skillelinjer kan sees $i$ at liberale sunni hadar er delt i tre konkurrerende grupper: Den nasjonale demokratiske alliansen (al-tahaluf al-watani aldimuqrati), Den demokratiske plattform (al-minbar aldimuqrati), og Den kuwaitiske arbeidsparaplyen (al-madhalla al-kuwaiti li-l-'amal).

I5 Shia-samfunnet (og shia-parlamentarikerne) er delt langs ideologisk-politiske skillelinjer knyttet til hvem man anerkjenner som øverste autoritet $\mathrm{i}$ religiøse spørsmål (marja' taqlid) og shiraziyya-retningen vs. da'waislamisme, men en av shia-representantene i nasjonalforsamlingen, Adnan al-Mutawwa, er i hovedsak valgt inn kraft av å representere shia-mulismene med opphav i alAhsa'.

I6 Hertog, Steffen: Princes, Brokers, and Bureaucrats: Oil and the State in Saudi Arabia. Ithaca New York: Cornell University Press, 2010.

I7 Sa'idi, Salih Baraka: al-sulta wa-l-tayyarat al-siasiya fi-lkuwait. Kuwait: Dar al-Qabas, 2010.

I8 Inntil 2003 holdt en og samme person posisjonen som statsminister og kronprins, så kontroll over statsministerposten er utvilsomt en viktig vei til den øverste makten.

I9 al-tajammu' al-salafi al-islami.

20 al-haraka al-salafiyya.

2I Lovendringen i 2006 hadde liten betydning for ytringsfrihetens grenser. Direkte kritikk av Gud, islam, Profeten og Emiren er fortsatt forbudt ved lov.

22 For mer informasjon om den kuwaitiske pressens historie se Selvik, Kjetil: "Elite Rivalry in a Semi Democracy: The Kuwaiti Press Scene", i Middle Eastern Studies, Vol. 47, No. 3, 20II.

23 Avisen ble imidlertid ingen stor suksess og stengte sommeren 20Io på grunn av finansielle problemer.

24 'alam al-yawm er registrert på to tidligere journalister med middelklassebakgrunn, Ahmad al-Jabr og 'Abd alHamid al-Da'as, og har ingen formell tilknytning til et spesielt parti eller samfunnssegment.

25 Al-Jaridas politiske orientering er til forveksling lik alQabas, økonomisk og politisk liberal. Intern konflikt med en annen eier av al-Qabas, Jasim al-Khorafi, skal ha vært grunnen til at Muhammad al-Saqr følte behov for å starte sin helt egen avis.

26 Se for eksempel "I.pdf," n.d., http://www.alshahedkw .com/pdf/92I/I.pdf. (05.02.II)

27 Awan tilhørte på papiret sosiologiprofessor ved Univer. sitet i Kuwait, Muhammad al-Rumaihi; al-Sabah er registrert på Barakat 'Awad al-Hudayban og al-Huriya på Mathni al-Farij.

28 Se for eksempel avisenes dekning av sikkerhetsstyrkenes angrep på opposisjonens diwaniyya 8 desember 20I0; "Sabah 09.I2.Io," n.d., http://www.alsabahpress.com/ SPress/Category.aspx?id=I5.; "al-Huriya o9.IO.I2," n.d., http://www.alhoriah.com/Horia News/default.aspx.
(05.02.II)

29 Kanal I, Kanal 2, Sport, Kuwait Plus og al-'Arabi.

30 De private satellittkanalene er al-Afasi tv, al-Shahid tv, alAnwar tv, al-Anwar tv2, al-Risala tv, al-Watan tv, al-Scope tv, al-Mukhtalif, al-Sabah tv, al-Kut tv og al-Adala tv. Enkelte av kanalene som al-Funun og al-Adala har i tillegg parallelle sendinger.

3I Mahmud Haydar eier også landets eneste private radiostasjon, Marina FM. Intervju med Hamid al-Enezi produksjonsansvarlig "Sabah al-Khayr", Kanal I, o8.I2.Io. Blant tv-kanalene Mahmud Haydar kontrollerer er alFunun, al-Funun +, al-Adala, al-Adala 2, Smile og Jahil (tidligere Flash). Han kjøpte nylig også $49 \%$ av NBN og Jaras i Libanon.

32 Forfatters intervjuer med sjefsredaktør i Awan, Muhammad al-Rumaihi, I8.03.09; sjefsredaktør i al-Ra'i, Yusuf alJalahme, 03.02.Io; og nyhetsredaktør i al-Jarida, Sa'ud alAnezi, 08.03.09.

33 Forfatters intervju med Ali al-Rayyes, Kuwait TV, o8.ı2.Io.

34 Kun tre aviser er til nå stengt på grunn av økonomisk fallitt: Awan, Arrouiah, og en kortlevd dagsavis som bar navnet al-Sawt.

35 Forfatters intervjuer med blant annet tidligere informasjonsminister og sjefsredaktør i al-Qabas, Anas Rusheed, o6.04.09; undersøkende journalist i al-Nahar, Zayed Zayd, o9.04.09; politisk kommentator i al-Jarida, Ghanim al-Najjar, 28.I2.o8; og sjefsredaktør i al-Qabas, Walid al-Nusif, 02.02.IO.

36 Sparrow, Bartholomew H.: Uncertain Guardians: The News Media as a Political Institution. Baltimore \& London: The Johns Hopkins University Press, I999.

37 Nasir al-Muhammad dro nytte av denne situasjonen ved å rekruttere dem til sin politiske leir.

38 Enkelte tv-kanaler sender faktisk bare i valgkampmånedene og stenger like etter.

39 Forfatters intervju med Ahmad Eissa og anonym informant som hadde ansvar for mediestrategien til to parlamentarikere ved valget i 2009 , o6.I2.Io.

40 Ibid.

4I Forfatters intervjuer med al-Jarida-skribent og leder for mediekontoret i Kuwaits parlament Mudhaffar Rashid, 09.03.09; al-Jarida-skribent og professor i økonomi ved Kuwait Universitet Abbas al-Mejren, I7.03.09 og redaktør i al-Qabas, Walid al-Nusif, 02.02.IO.

42 “SCOPE TV ATTACKED," n.d., http://www.arabtimeson line.com/NewsDetails/tabid/96/smid/4I4/ArticleID/ I $60833 / \mathrm{reftab} / 96 / \mathrm{t} / \mathrm{S}$ COPE-TV-ATTACKE D/ Default.aspx. (05.02.II). 